\title{
Las humanidades en la formación profesional
}

Fernando Lolas Stepke 1,a

1 Universidad de Chile, Facultad de Medicina, Centro interdisciplinario de Estudios en Bioética, Santiago, Chile.

a Doctor honoris causa.

\section{Correspondencia:}

Fernando Lolas Stepke: flolas@uchile.cl

Diagonal Paraguay 265 Of. 806. Santiago- Chile.

ORCID: 0000-0002-9684-2725

Recibido: $11 / 08 / 20$

Aceptado: $17 / 08 / 20$

Publicado: $16 / 11 / 20$

\section{The humanities in professional training}

Bajo el término humanidades solía entenderse en el Renacimiento europeo el cultivo de las perfecciones atribuidas a la Antigüedad clásica. Más ampliamente, el término designa aquellas disciplinas y saberes que complementan las actividades lucrativas con sensibilidad estética, conciencia histórica y discernimiento ético.

Una profesión es una respuesta institucionalizada a una demanda social. Las personas que integran un grupo profesional se hallan ligadas por una base común de conocimientos y métodos, además de un sentido de pertenencia que asegura adhesión a un código de comportamiento.

Las profesiones modernas, esencialmente, reciben recompensas en dinero, prestigio, poder y aprecio social. El dinero se entiende que no es la finalidad esencial de su ejercicio, y en algunas profesiones se llama "honorario", para distinguirlo de jornal o sueldo.
En toda profesión hay estratos constituidos por personas que renuevan sus conocimientos y técnicas ("investigadores"), por las que velan por sus exclusividades y fueros (evitando que personas no capacitadas ejerzan) y finalmente por aquellas que desempeñan el oficio de ayuda a quienes lo requieren. Estas personas, la gran mayoría, no solamente deben saber lo que hacen. También deben hacerlo bien. Todo ejercicio profesional es un saber-hacer, dominar el conocimiento bajo condiciones de incertidumbre y siguiendo las reglas de su comunidad ilustrada.

Además de saber-hacer, en la dignidad del ejercicio profesional, ha de incluirse un saber-estar. Velar por el prestigio y credibilidad del grupo profesional supone identificación con sus misiones y aceptación de normas de conocimiento y práctica. También puede agregarse, como parte del ethos profesional, la función de hacer-saber, pues los profesionales también enseñan al público y a sus pares ${ }^{1}$. 
En estas tres dimensiones -saber-hacer, saber-estar y hacer-saber- no basta con dominar los saberes y técnicas, adherirse a códigos de conducta o difundir los conocimientos, sino, tomar en cuenta el modo como se ejecutan. En este modo interviene el concepto de las humanidades. Pues no se trata solo de saber qué, cuándo y cómo prestar servicios. Se trata, además, de hacerlo en forma tal que enriquezca al profesional, brinde una empática aceptación de la solicitud de ayuda y agregue un mérito emancipatorio. Por tal se entiende un enriquecimiento de las dimensiones interpersonales.

Todo acto profesional puede evaluarse en tres dimensiones. Ha de ser, primero, técnicamente correcto, según lo prescribe el conocimiento validado empíricamente. Luego, ha de estar bien hecho, en el sentido de brindar satisfacción a quien lo experimenta y a quien lo realiza. Finalmente, los resultados han de ser justos, es decir equitativamente distribuidos en la población ${ }^{2,3}$.

Cuando nos referimos a "formación humanística" no significa agregar simplemente algunas disciplinas en los recargados programas de estudio. Queremos sugerir que se complementen las disciplinas del estudio con sensibilidad estética, con reflexión ética y con conciencia histórica. Estas adquisiciones de los profesionales son difíciles de transmitir y más difíciles aún de ponderar y juzgar. Han de quedar como ideales. Pero al hacérselas conscientes deben servir, al menos, como legítimas aspiraciones de las instituciones de enseñanza superior.

\section{Referencias bibliográficas}

1. Lolas F. La psiquiatría como saber-hacer, saber-estar y hacer-saber [editorial]. Salud ment. 2008;31(5):341.

2. Lolas F. Dimensión bioética de las profesiones. En: Lolas F, Drumond JGF, editores. Bioética. Santiago de Chile: Mediterráneo; 2013. p. 47-56.

3. Lolas F. Ética y reflexión crítica de los profesionales. En: Montero A, Nińo R, editoras. Bioética en salud sexual y reproductiva. Santiago de Chile: Mediterráneo; 2015. p. 46-50. 